\title{
Waste Management for Environmental Safety in The Effort to Support Biosafety of Agricultural Biotechnology Products University of Jember
}

\author{
Arnis Budi SUSANTO ${ }^{1 *}$, Andriana ${ }^{2}$, Dian ANGGRAENI ${ }^{3}$ \\ 1,2Faculty Economics and Business, Universitas Jember, Indonesia \\ ${ }^{3}$ faculty of math and Science, Universitas Jember, Indonesia \\ Email: arnis.feb@unej.ac.id ${ }^{1}$, Andriana.feb@unej.ac.id², Dian_a.fmipa@unej.ac.id ${ }^{3}$ \\ * Corresponding Author
}

\begin{abstract}
Received: 02.11.2021
\end{abstract}
Accepted: 04.12.2021

Published: 02.02.2022

DOI: 10.47750/QAS/23.186.25

\begin{abstract}
The purpose of this study was to obtain information on waste management of biotechnology products, which focused on agricultural products at the University of Jember, namely golden rice (oryza sativa indica var) and transgenic sugarcane. Furthermore, the results of this study can be used as a source of information for waste management and predicting waste production so that it can be the basic material for policies in waste management in the future. Interview and literature study. The research was conducted by conducting interviews with relevant leaders and resource persons related to the research topic. In addition, in the first year, the forecast uses the ensemble forecasting method.
\end{abstract}

Keywords: Waste Management, Biotechnology, environmental safety

\section{Introduction}

Jember University has superior resources related to research and development of biotechnology products (Susanto, Titisari, \& Andriana, 2019). The results of previous studies indicate that the University of Jember has a typology based on academic research in the field of biotechnology which supports the development of biotechnology products as the flagship of the University of Jember. This can illustrate that the University of Jember has a real contribution in producing biotechnologythemed research and also the development of biotechnology products so that it can be said that the University of Jember is a center of excellence.

Jember University as one of Indonesia's centers of excellence in the field of industrial plant biotechnology has developed several biotechnology products. Some of the biotechnology products produced are golden rice (oryza sativa indica var) and transgenic sugarcane. The development of this product has been carried out by researchers coordinated by a research group, namely CDAST (Center for Development of Advance Science and Technology). In its management, biotechnology products will also inevitably generate waste during the process. In this biotechnology product, there are two kinds of waste, namely process waste and post-harvest waste. Process waste appears during the engineering process carried out in the laboratory, while post-harvest waste is waste that arises related to planting trials carried out.

Problems regarding the management of hazardous and toxic waste (B3) are currently the focus of the State Ministry of Environment (KNLH) (Andriana \& Susanto, 2018). Various activities that produce waste that has the potential to contaminate land will be very detrimental to the surrounding environment. The high cost of waste treatment is the main reason behind the lack of attention regarding waste management. In addition, the availability of technology and resources is also a reason for waste management.

So far, waste management for modern biotechnology has been carried out referring to the Minister of Environment Regulation No. 30 of 2009 concerning procedures for permitting B3 waste management. In practice it is necessary to manage and comply with these regulations which are embodied in the SOP for waste treatment. This research is a study that looks at the compliance with regulations and the processing of B3 waste from modern bitechnology carried out by the University of Jember as well as forecasting related to B3 waste produced by biotechnology.

This research focuses on biotechnology products in the agricultural sector, which are devoted to golden rice and transgenic sugarcane products. These two biotechnology products were chosen because they have two types of waste, namely process and post-harvest waste.

In this study, further observations will be made on the compliance and management of B3 waste from biotechnology, and also forecasts related to B3 waste in the future as the basis for policies for the management of waste produced by biotechnology. One of the results of this research is to provide recommendations and input regarding the management of $B 3$ waste treatment from Biotechnology at the University of Jember as PUI Bio Tin.

The purpose of this study was to obtain information on waste management of biotechnology products, which focused on agricultural products at the University of Jember, namely golden rice (oryza sativa indica var) and transgenic sugarcane. 
Furthermore, the results of this study can be used as a source of information for waste management and predict waste production so that it can be used as a basis for policies in waste management in the future.

\section{Literature Review}

\section{Biotechnology}

Biotechnology is the integrated use of biochemistry, microbiology and various sciences with the help of microbes and their technological and industrial applications. Biotechnology can also be said as a process that starts from input in the form of raw materials which is then processed by biodegradation or compilation into an output in the form of goods or services.

Biotechnology can be divided into two kinds. Conventional biotechnology is often referred to as traditional biotechnology. Understanding conventional biotechnology can be interpreted as an application of biotechnology using simple methods and equipment. Usually, conventional biotechnology activities only utilize organisms in the fermentation process. Conventional biotechnology is carried out when science is still not developing rapidly. Unlike conventional biotechnology, modern biotechnology uses very sophisticated equipment, technology, and methods. Not everyone can carry out modern biotechnology activities. In addition to using sophisticated equipment and technology, special skills and knowledge are needed to carry out this type of biotechnology activity.

\section{Government Regulations related to Waste Management}

Government Regulation No. 101 of 2014 concerning Management of Hazardous and Toxic Waste. Article 1 Number 11, B3 Waste Management is an activity that includes: reduction, storage, collection, transportation, utilization, processing and/or landfilling. B3 Waste Reduction is carried out through material substitution; Process modification; and/or, Use of environmentally friendly technology. In Article 12 to Article 30 of PP Number 101 of 2014 it is obligatory to store B3 waste for everyone who produces B3 waste. It is forbidden to mix the stored B3 waste. B3 Waste storage must be equipped with a B3 Waste management permit for B3 Waste storage activities. B3 Waste Management Permit for hazardous waste storage activities is issued by the regent/mayor.

The packaging of B3 Waste is carried out using packaging which: (1) is made of materials that can pack B3 Waste in accordance with the characteristics of the B3 Waste to be stored; (2) able to contain the B3 Waste to remain in the packaging; (3) have a strong cover to prevent spillage during storage, transfer or transportation; and (4) are in good condition, not leaking, not rusting, or undamaged. B3 Waste Packaging must be attached with a B3 Waste Label and B3 Waste Symbol. The hazardous waste label shall at least include information regarding: (1) the name of the hazardous waste; (2) the identity of the hazardous waste generator; (3) the date the hazardous waste was generated; and (4) the date of packaging of the hazardous waste

\section{Research Methods}

This research is a study that uses a mix method, where the first research (2020) was conducted using a survey model with in-depth interviews and literature study. The research was conducted by conducting interviews with relevant leaders and resource persons related to the research topic. In addition, in the first year, the forecast uses the ensemble forecasting method.
Meanwhile, in the second year, a grounded research approach will be carried out which will produce policies in terms of managing waste from biotechnology products at the University of Jember.

This research was conducted at the University of Jember including PUI-BioTin, PIU IsDB UNEJ, CDAST Laboratory, Faculty of Agriculture, University of Jember. The period of this research was conducted for 2 (two) years. Where in the first year, phenomenology and forecasting were carried out regarding the management of waste from biotechnology products at the University of Jember, especially in the agricultural sector, namely smart rice and transgenic sugarcane. In the second year, a grounded research approach was conducted which resulted in the waste management policy.

This study uses two types of data, namely primary data in the form of in-depth interviews with relevant informants and secondary data derived from existing data at the University of Jember and also literature studies.

\section{Research Result}

\section{Sugarcane Artificial Seed}

The low productivity of sugar cane can be caused by the low quality and availability of sugar cane seeds. The quality and number of seeds is a determinant of success in the production process in achieving profits in the agricultural sector. Technology for producing quality sugarcane seeds that are readily available in large quantities is needed to support the sugar self-sufficiency program. Propagation technique through somatic embryogenesis has the potential to be developed because it can produce an unlimited number of propagules in a short time. These embryos can be produced through tissue culture and can be developed for synthetic seed techniques (artificial seed). Synthetic seeds (artificial seeds) are seeds resulting from encapsulation techniques carried out on somatic embryos, shoot meristems, axillary buds or other meristem tissues. This technique is one of the modern techniques and has been widely applied in the field of plant biotechnology such as mass clonal propagation and conservation of germplasm. PUBioTIn has succeeded in obtaining a superior synthetic seed production method free of SCMV virus. The success of this research is expected to guarantee the availability of healthy sugar cane seeds in large quantities so that they can support the government's program for sugar self-sufficiency (Parawita Dewanti. et al. 2016).

\section{Golden Rice}

Golden rice is a genetically modified rice that can produce carotene (provitamin A) which is expected to help overcome vitamin A deficiency. Carotenoids are part of the pigment in plants that are important for nutritional needs for humans and are precursors of vitamin A. Deficiency Provitamin A is a major public health problem in the world, a lack of provitamin A can cause permanent blindness and susceptibility to infectious diseases. In Asia, especially, the problem of lack of provitamin A intake, this is often associated with the dominant pattern of consumption of rice as a staple food. So from this situation, special efforts are needed to increase the content of vitamin A in the seeds, namely the endosperm. In plant breeding molecularly it is important to obtain superior varieties that accumulate important genetic traits. By combining gene transformation and plant breeding techniques, it is possible to transfer parts of provitamin A transgenics into new varieties that have superior traits, or assemble at the same time transferring transgenes with superior traits brought by the main background, namely transgenic plants into background form. novel that can 


\section{GENERAL MANAGEMENT}

accumulate transgenes and several superior traits carried into a single one. The Nagdong variety is a transgenic background of provitamin A rice PAC, Nagdong has the characteristics of resistance genes to the stripe virus carried by planthoppers, has high stems, but has lower yields when compared to superior Japonica cultivars. Previous research PAC/Nagdong has been successfully crossed with IR36 semi-dwarf by molecular breeding. IR36 is an indica rice cultivar, which has the

\section{Reference}

[1] Andriana, A., \& Susanto, A. B. (2018). Waste Treatment Compliance Audit at the Jember University Medical Center Unit. Journal of Accounting, Economics and Business Management| E-Issn: 2548-9836, 6(1), 102-106.

[2] Moelong, L. J. (2007). Quantitative Research Methods. Bandung: Rosdakarya Youth.

[3] Safitri, F. A., Ubaidillah, M., \&nbsp, M., \& Kim, K.-M. (2013). Response of Explants of Calli Rice (\&lt;i\&gt;Oryza sativa\&lt;/i\&gt; L.) Japonica cv. "IImi" to Gene Transformation Using \&lt;i\&gt;Agrobacterium tumefaciens\&lt;/i\&gt;-Mediated. American Journal of Plant Sciences, 04(04), 838-843. doi:10.4236/ajps.2013.44102

[4] Susanto, A. B., Titisari, P., \& Andriana. (2019). Typology innovation business model for university as centers of science based on biotechnology. International Journal of Scientific and Technology Research, 8(5), 44-47.

[5] ---------, Minister of Environment concerning Wastewater Quality Standards, Minister of Environment No. 5 of 2014.

[6] ---------, Government Regulation on Management of Hazardous and Toxic Waste, Government Regulation No. 101 of 2014.

[7] ----------, Minister of Environment concerning Procedures for Licensing and Supervision of B3 Waste Management and Recovery Due to B3 Waste Pollution by the Regional Government, Environmental Ministerial Regulation No. 30 Year 2009

[8] -----------, Minister of Environment concerning Procedures for Licensing for B3 Waste Management, Minister of Environment No. 18 of 2009 . characteristics of high yield potential and is resistant to various pests and diseases. In addition, IR36 can be harvested in a fast time of 105 days. The PAC/IR36 crosses that have been selected then need to be re-breeded with important local varieties. This needs to be done on the grounds of the transfer of important genetic traits inherited by the progeny and it is hoped that the progeny will inherit superior genetic traits from the parent donors used (Safitri et al., 2013). 